\title{
EFFECTS OF ACUTE INTRACEREBROVENTRICULAR MICROINFUSIONS OF BUPROPION ON BACKGROUND SPIKE ACTIVITY OF LOCUS COERULEUS NEURONS IN RATS
}

\author{
Received 5.12.2013
}

Considering that noradrenergic (NAE) neurons of the locus coeruleus (LC) play significant roles in the formation of biological rhythms, pain, addictions, and mood disorders, we tested the effects of acute intracerebroventricular microinfusions of bupropion, an inhibitor of NA reuptake used in clinics as an antidepressant, on background spike activity on LC neurons in chloral-hydrate anesthetized rats. Ten microliters of the solutions containing $0.001,0.01,0.1$, 1.0 , or $10.0 \mu \mathrm{mol}$ bupropion were infused during $3 \mathrm{~min}$; spike activity of single LC neurons identified according to the known characteristics was recorded extracellularly by glass microelectrodes. Microinfusions of 0.01 to $10.0 \mu \mathrm{mol}$ bupropion suppressed background spiking of the above neurons in a dose-dependent manner. The normalized mean intensities and durations of inhibition were $17.3,19.4,26.3$, and $41.1 \%$ and $1.4,7.1,12.4$, and $18.3 \mathrm{~min}$, respectively. The smallest dose $(0.001 \mu \mathrm{mol})$ was ineffective. It is assumed that bupropion increases the NA level in proximity to NAE LC neurons. The actions of bupropion on other cerebral neuromodulatory systems need further examination. Inhibition of LC neuronal activity by bupropion can help to explain some acute, chronic, and side effects of this agent used in clinics for correction of mood disorders.

KEYWORDS: locus coeruleus neurons, background impulse activity, firing rate, bupropion, intracerebroventricular microinfusions.

\section{INTRODUCTION}

The noradrenergic (NAE) neurons of the locus coeruleus (LC) play essential roles in the control of important biological phenomena such as sleep, cardiovascular control, depression, etc. [1]. The monoamine hypothesis of depression genesis was proposed in 1965; as was assumed, monoamines, noradrenaline (NA) in particular, are likely to be the key elements in the etiology and progression of depression. This hypothesis motivated researchers to

\footnotetext{
${ }^{1}$ Neurophysiology Research Center, Urmia University of Medical Sciences, Urmia, Iran.

${ }^{2}$ Department of Physiology, Faculty of Medicine, Urmia University of Medical Sciences, Urmia, Iran.

${ }^{3}$ Danesh Pey Hadi Co., Faculty of Medicine, Urmia University of Medical Sciences, Urmia, Iran.

${ }^{4}$ Department of Histology \& Embryology, School of Medicine, Dokuz EyluL University (DEU), Izmir, Turkey.

${ }^{5}$ Biology Department, Payame Noor University, Teheran, Iran.

${ }^{6}$ Tabriz Neuroscience Research Center, Tabriz Medical Science University, Tabriz, Iran.

Correspondence should be addressed to: F. G. Pakdel (e-mail: info@fgpakdel. com, fgpakdell@umsu.ac.ir, fgpakdell@yahoo.com)
}

elucidate the roles of monoamine neurotransmitters, serotonin (5-hydroxytryptamine, 5-HT), noradrenaline (NA), and dopamine (DA), in the pathogenesis of depression. Further development of the catecholamine hypothesis proposed that depression may be related simply to a deficiency of catecholamines, mostly of NA [2]. However, both elevations and reductions in the level of NA or its metabolites have been demonstrated in the cerebrospinal fluid (CSF), plasma, and urine of depressed patients, and this made controversial the respective statements on the involvement of NA in the initiation of depression [3].

According to the monoamine hypothesis on the etiology of depression, the LC plays a major role in the respective disorders [4]; the deficiency of monoamines in the brain regions is the major factor for the development of depression, and most antidepressant drugs increase the synaptic availability of monoamines [5-7]. However, convincing evidence of a primary role of dysfunction of the specific monoamine brain systems in patients with major depressive disorders has not been found [5].

Although the main effects of antidepressants were 
thought to be reflected in the activation of LC neurons, studies of LC neuronal activity revealed a paradoxical evidence of both decreased density of neurons and increased tyrosine hydroxylase activity [8,9]. Chronic administration of some antidepressants can decrease background and burst evoked firing of LC neurons $[10,11]$. Recently, West et al. reported that an antidepressant, paroxetine, increased LC neuronal activity in young rats [12]; thus, it was shown that the effect of some antidepressants on LC neuronal activity may be unique.

As was reported, acute systemic administration of bupropion in rats inhibited LC-NAE neuronal activity. This inhibition appeared unrelated to a direct action of bupropion on LC-NAE neurons or to its modulatory action on other neurotransmitters in the brain regions. Metabolites of bupropion can alter neuronal activity of the above neurons [13]. Desipramine, an NA reuptake blocker, was found to inhibit LC neuronal activity, but the nature of such inhibitory effects exerted by its metabolites or itself was not convincingly interpreted [14]. In our recent study, we assumed that bupropion may increase the activity in the ventral tegmental area indirectly via inhibition of GABAergic neurons [15].

We assume that inhibition of LC neuronal activity by bupropion is provided by the direct action of bupropion on NA receptors localized on the dendrites and/or soma of LC-NAE neurons. This study was designed to test the effects of intracerebroventricular (ICV) acute microinfusions of bupropion on impulse neuronal activity in the LC and to evaluate the direct/ indirect nature of the effect of this agent.

\section{METHODS}

Healthy male Wistar rats (Pasteur Institute, Iran; body mass 250-280 g) were used. Animals were housed three in a cage at a $12 \mathrm{~h}$ light/dark cycle $(7: 00 \mathrm{a} . \mathrm{m}$. to 7:00 p.m.) and controlled temperature $\left(22 \pm 2^{\circ} \mathrm{C}\right)$ with food and water ad libitum. Animals were divided into seven groups: control, sham, and five groups microinfused with solutions containing different amounts of bupropion ( $n=6$ to 12 rats in each group). The rats were anesthetized with chloral hydrate $(400 \mathrm{mg} / \mathrm{kg}$, i.p.; the booster dose was about $10-15 \%$ of the initial dose) and secured in a stereotaxic instrument (Stoelting, USA). The body temperature was monitored continuously and maintained at $\sim 37^{\circ} \mathrm{C}$ throughout the experiment. The bregma and interaural stereotaxic coordinates were measured for each rat, and the location of the opening for $\mathrm{LC}$ recording was determined according to the rat stereotaxic brain atlas [16].

Single unit spike activity was recorded from LC neurons as described previously [17]. Briefly, after anesthesia and opening of the skull, a glass microelectrode (in vitro impedance 3-6 M $\Omega$ ) filled with a $2 \%$ solution of Pontamine Sky Blue in $0.5 \mathrm{M}$ sodium acetate was inserted in the brain into the region of $\mathrm{LC}$ 1ocalization (Bregma -9.84, ML 1.35, and DV $6.8 \mathrm{~mm}$ with respect to the bregma zero-zero plane) until single neuronal activity could be clearly detected. For all neuronal recordings, the criteria described earlier [1821] were taken into account. These criteria were the following; (i) long-lasting positive-negative waveform with a notch, (ii) biphasic excitation-inhibition responses to contralateral hind paw pinch, and (iii) regular background activity with a relatively low firing rate $\left(0.5-5.0 \mathrm{sec}^{-1}\right)$. The units satisfying the mentioned criteria were recorded in the case of stable amplitude and firing rate. The recorded activity was filtered (bandpass $300-3000 \mathrm{~Hz}$ ), amplified, digitized, and addressed to a PC computer (Electromodule 3111 data acquisition system, Http://www.sciencebeam.com/). Digitized data were displayed on an oscilloscope using NeuroComet software (Http://www.sciencebeam.com). This software was also used for window discrimination of spikes and analysis of the activity. Peri-stimulus time histograms (PSTHs) for single units were plotted with 1-msec-long bins. Sensitization or desensitization of the recorded units was tested by contralateral hind paw compression. All units with no respective shifts were included in the analysis. Frequency graphs were also plotted for estimation of the firing rate stability.

The PSTHs extracted on-line or off-line were checked again by a blind-control person. Samples of spiking used for plotting PSTHs and current frequency graphs were 5 min long. In each record, the spiking stability was estimated within a 5-min-long interval, and a subsequent 10-min-long interval was used for baseline estimation. Forty-min-long recordings were used for assessing possible effects of infusions of artificial cerebrospinal fluid (ACSF) or the drug (bupropion), with cut-off on the 60th min.

For bupropion infusion, a 30-gauge stainless steel needle was connected to a $10 \mu 1$ Hamilton syringe by a polyethylene tube. The needle was stereotaxically inserted into the right lateral ventricle. The drug vehicle (ACSF) or solutions containing different amounts of bupropion were injected by a microsyringe pump. The volumes of all injections were $10 \mu \mathrm{l}$, and the duration of infusion was $3 \mathrm{~min}$. Concentrations of bupropion 
in the solutions used for microinfusions were 0.0001 , $0.001,0.01,0.1$, and $1.0 \mathrm{M}$; thus, the amounts of infused bupropion, considering the volume of infusions $(10 \mu \mathrm{l})$, were $0.001,0.01,0.1,1.0$, and $10.0 \mu \mathrm{mol}$, respectively.

After the experiments, all animals were deeply anesthetized and perfused with $10 \%$ phosphate-buffered formalin solution. The brains were removed and fixed in the perfusion solution. Coronal $40-\mu \mathrm{m}$-thick sections were prepared on a microtome and stained by Fast Cresyl Violet. The trajectory path and location of the infusion cannula tip were verified under a light microscope. The rats with unsuccessful injections were excluded from the analysis.

Drugs, chemicals, and equipment used in our study included bupropion, formalin, Pontamine Sky Blue, Fast Cresyl Violet, chloral hydrate (Sigma-Aldrich, USA), sodium acetate and sodium chloride (Merck, Germany), polyethylene microtubes (A-M system, USA), and Hamilton microsyringes (Hamilton Bonaduz AG, Switzerland).

Numerical data of the firing rate of single units were analyzed using one-way analysis of variance (ANOVA). Analysis of the effect of different doses of the drug was carried out using ANOVA and the Tukey's posthoc test. $P<0.05$ indicated the least statistical significance in intergroup comparisons. Numerical data are shown below as means \pm s.d.

\section{RESULTS}

An example of the typical LC neuronal spike is shown in Fig. $1 \mathrm{~A}$; the upper and lower levels of window dis-
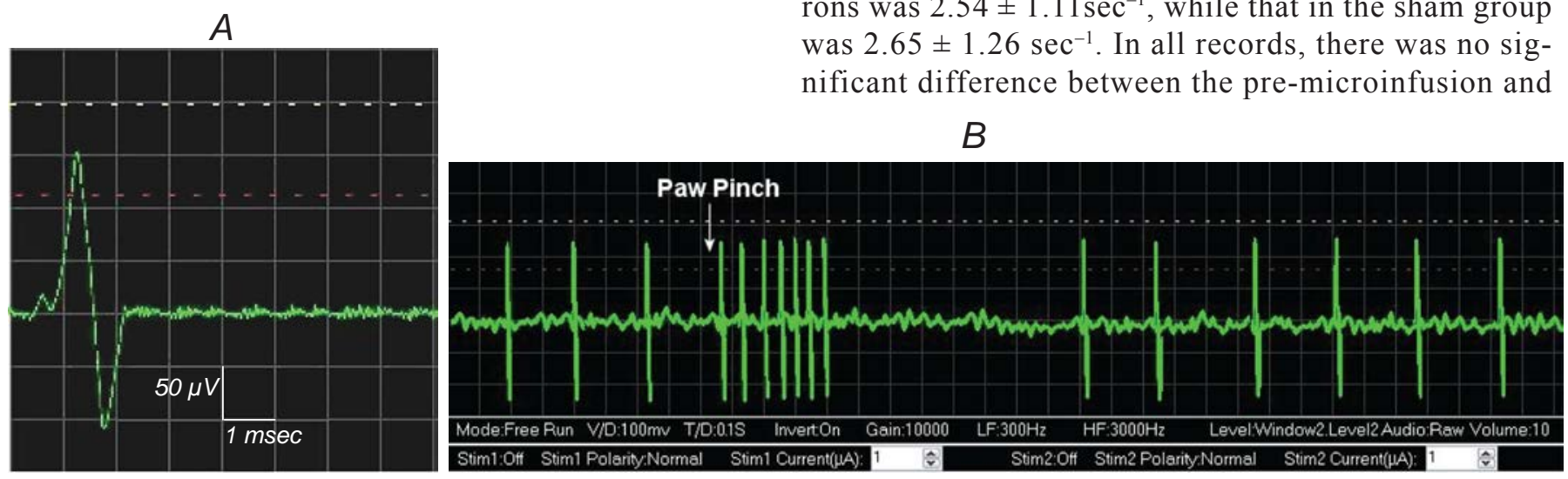

F i g. 1. Pattern of spike activity recorded from locus coeruleus (LC) neurons. A) Waveform of a typical extracellularly recorded single unit spike of an LC neuron. A notch on the ascending spike limb is seen; limits for window discrimination by NeuroComet software are shown. B) Typical response of an LC neuron to a brief pinch of the contralateral paw. Background firing of this neuron was low-frequency and regular. The sensory-evoked response was followed by a silence period (post-stimulus inhibition).

Р и с. 1. Патерн імпульсної активності, що відводиться від нейронів блакитної плями (LC). 

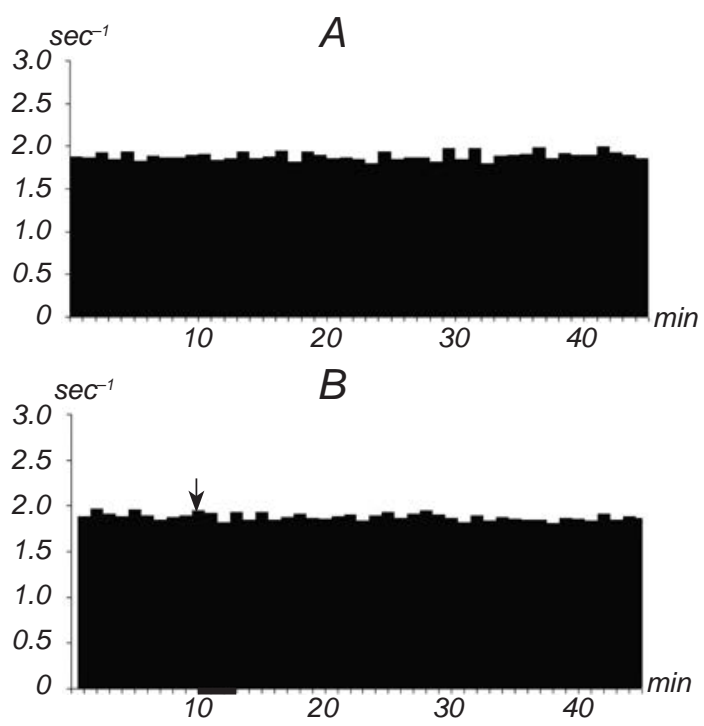

F i g. 2. Frequency graphs of background activity generated by locus coeruleus (LC) neurons. A) Graph illustrating a stationary pattern of background spiking of an LC neuron. B) Graph illustrating the absence of a significant effect of intracerebroventricular infusion of the vehicle (ASCF) on background activity of an LC neuron. The moment of beginning (arrow) and duration of infusion are shown above the graph and on the abscissa, respectively.

Р и с. 2. Графіки частоти фонової активності, генерованої нейронами блакитної плями $(L C)$.

post-microinfusion periods.

Figure 3 shows the effects of different ICV-infused bupropion doses $(0.001,0.01,0.1,1.0$, and $10.0 \mu \mathrm{mol})$ on the background firing rate of five LC neurons. It is obvious that bupropion-induced effects are clearly dose-dependent. Doses of 0.01 to $10.0 \mu$ mol provided noticeable inhibition of LC activity, while there was no significant inhibitory effect of the lowest bupropion dose $(0.001 \mu \mathrm{mol})$.

The significant dependence of the intensity of bupropion-induced suppression of background impulse activity generated by LC NAE neurons and the time course of this inhibition are more clearly visible on a graph of normalized changes in this activity for the entire examined group. The effects of infusions of 0.001 , $0.01,0.1,1.0$, and $10.0 \mu \mathrm{mol}$ bupropion were examined on 22, 28, 23, 29, and 34 LC neurons, respectively. The mean normalized intensities of decreases in the rate of background firing were $1.41 \pm 0.12,7.14 \pm$ $\pm 4.85,12.40 \pm 3.11$, and $18.30 \pm 5.45 \%$ for the doses of infused bupropion of $0.01,0.1,1.0$, and $10.0 \mu \mathrm{mol}$, respectively (Fig. 4, 2-5). In all cases, the firing rates of LC neurons within the pre-microinfusion period were taken as $100 \%$. The maxima of bupropion-evoked inhibition of spiking were also shifted with increase

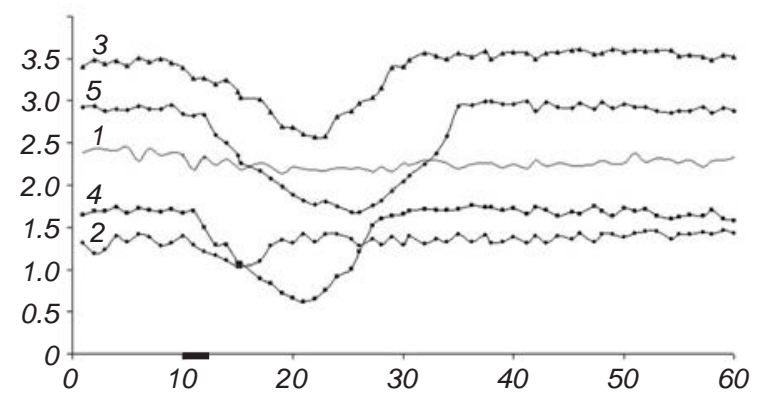

F i g. 3. Effects of different doses of ICV-microinfused bupropion $(0.001,0.01,0.1,1.0$, and $10.0 \mu \mathrm{mol}, 1-5$, respectively) on background firing of five LC neurons (1-5). The time of infusion is indicated on the abscissa.

P и с. 3. Впливи внутрішньошлуночкових мікроінфузій різних доз бупропіону $(0.001,0.01,0.1,1.0$ або 10 мкмоль, 1-5 відповідно; 10 мкл/3 хв) на фонові розряди п'яти нейронів $L C$ $(1-5)$.

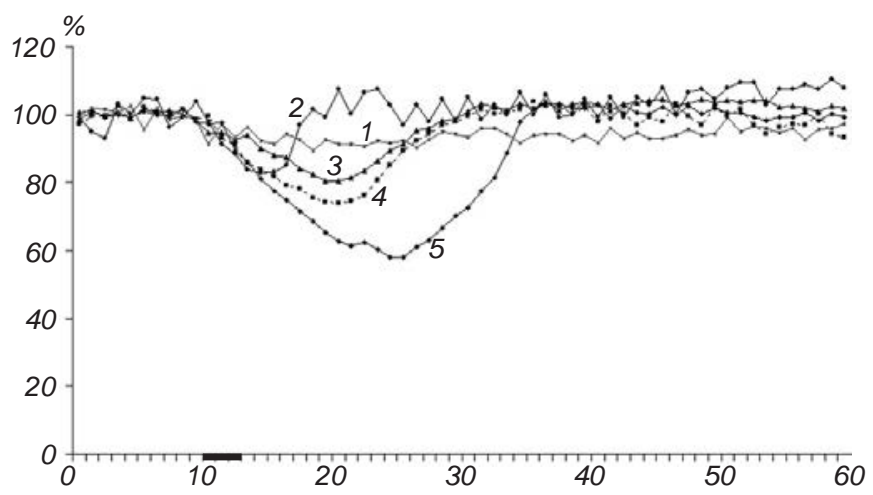

Fig. 4. Averaged normalized bupropion-induced changes, \%, in the firing rate of the examined LC neurons. The mean firing rates within the pre-infusion period were taken in each case as $100 \%$. Other indications are similar to those in Fig. 3.

Р и с. 4. Усереднені по групі нормовані зміни (\%) частоти розряду досліджених нейронів $L C$, викликані інфузіями бупропіону

in the dose of the infused drug, and the total duration of inhibition increased (Fig. 4). The duration of suppression of impulsation was calculated by repeatedmeasure ANOVA for determination of the differences between points. The averaged durations of such suppression at the above-mentioned bupropion doses were $1.41 \pm 1.20,7.14 \pm 4.85,12.40 \pm 3.11$, and $18.00 \pm$ $\pm 4.45 \mathrm{~min}$, respectively. These data are summarized in the diagrams of Fig. 5. The smallest infused bupropion dose $(0.001 \mu \mathrm{mol})$ provided no significant effect on LC neuronal firing rate $(P=0.23)$.

\section{DISCUSSION}

Our electrophysiological data demonstrated that 


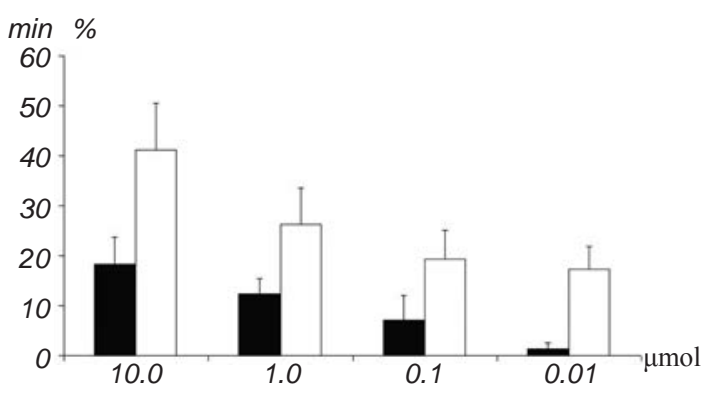

Fig. 5. Dose dependence of the effects of ICV microinfusions of bupropion on the duration (filled columns, min) and maximum inhibition (open columns, \%) of LC background spike neuronal activity. The duration of inhibition of the activity was calculated by repeated-measure ANOVA for determination of the differences between points. The maximum inhibition was estimated as the average in the experimental groups. The mean firing rates within the pre-infusion period was assumed as $100 \%$. Asterisks, crosses, and diagonal crosses indicate cases with $P<0.05$ in comparison to groups treated with $10.0,1.0$, and $0.1 \mu \mathrm{mol}$, respectively. ANOVA with post-hoc Tukey's protected $t$-test was used.

Р и с. 5. Дозозалежність характеристик гальмування (тривалості, хв, та максимальної інтенсивності гальмування, \%), фонової імпульсної активності (чорні та білі стовпчики відповідно) під впливом мікроінфузій бупропіону.

acute ICV microinfusions of bupropion, an NA reuptake inhibitor frequently qualified as an atypical antidepressant, are capable of significantly suppressing background neuronal activities of single LC neurons in a clear dose-dependent manner. No dramatic sensitization or desensitization in the influence of bupropion on LC neurons was observed, and this agent could inhibit the above background neuronal activity for a few minutes.

Hypotheses on the mechanisms by which antidepressants, such as bupropion, can produce inhibition of LC neuronal activity are controversial. The main suggested mechanism for inhibition of LC neurons by antidepressants is the involvement of NA reuptake blocking in the vicinity of the dendritic tree and/or soma of these neurons. Blocking of this reuptake process by bupropion is consistent with a strong inhibitory action on LC firing that is exerted via stimulation of somatodendritic alpha-2 NA receptors localized on LC neurons. The elevated NA level in close proximity to somatodendritic synapses results in more intense binding of NA to alpha-2 receptors and provides hyperpolarization of LC neurons. This effect can be mimicked by clonidine (an alpha 2-adrenoceptor agonist) [22-24]. Not only NA reuptake inhibitors, but also other inhibitors influencing biogenic amines, in particular 5-HT reuptake inhibitors, can suppress spiking of LC neurons. The respective findings revealed that serotonergic receptors are localized on the LC cell bodies, and the action of 5-HT within the regions adjacent to these receptors inhibits LC activation [25]. Therefore, any agent that can increase the NA concentration in the synaptic environment can inhibit LC impulse activity. Monoamine oxidase (MAO) inhibitors can also suppress spiking of LC neurons by increasing the NA level [26].

Observations made in our study on the inhibitory action of acute ICV infusions of bupropion are consistent with what other investigators found after administration of antidepressant drugs [27-29]. There were reports, however, that chronic administrations of some antidepressants did not decrease background or sensory-evoked LC neuronal activity due to manifestations of tolerance under conditions of chronic action of these drugs $[28,30,31]$. It should be taken into account that tolerance could not significantly develop in our experiments where acute action of bupropion was tested.

The involvement of NA receptors of LC neurons in the pathogenesis of major depression (MD) has been studied in post mortem cases. Based on the data of many researches, an abnormal state of the central NAE system was proposed to play an important role in the pathophysiology of this disease. Alpha-2 adrenoreceptors throughout the LC were found to be significantly elevated in patients suffering from MD compared to the matched control subjects [32]. Increased levels of tyrosine hydroxylase and decreased levels of the NA transporter (NAT) imply NA deficiency in the LC related to MD. The NAT is a membrane protein responsible for termination of the action of synaptic NA and is a site of action for many drugs used to treat MD [33].

The mechanism of reduction of the LC neuronal firing rate due to acute ICV infusions of bupropion is not fully understood. There is well-known evidence that the effect of bupropion (a rapid and significant drop in the firing rate of LC cells) is antagonized by yohimbine and piperoxane (alpha-2 adrenergic antagonists), implying that there is ultimately activation of alpha-2 receptors in the rat brain [34]. An indirect mechanism of bupropion for suppression of LC firing does not completely explain the effect of this drug on LC neurons because inhibition of NA uptake can be demonstrated in vivo only at tenfoldhigher doses [35]. At the same time, our findings on the action of bupropion are consistent with what other researchers reported after acute administration of antidepressant drugs [27-29, 36, 37]. 
The acute antidepressant effect of bupropion is more closely associated with its action on the firing rate of NAE LC neurons than with its effect on midbrain mesolimbic dompaminergic neurons. These results confirm previous findings $[10,11,38]$.

Thus, we found that ICV microinfusions of the atypical antidepressant bupropion inhibit background impulse activity of LC-NAE neurons in chloral hydrate-anesthetized rats in a dose-dependent manner. A detailed understanding of the pharmacological properties of bupropion should help to establish the true efficacy of its action on NA uptake. Potent interactions of bupropion with cholinergic, histaminergic, serotonergic, and dopaminergic systems in the brain should be examined for adequate interpretation of the effects of this drug. At the same time, our data add some information helping to explain acute, chronic, and side effects of bupropion used in clinics for correction of mood disorders.

Acknowledgment. This work was supported by grant No. 1029 to F. G. Pakdel by the Research Council of the Urmia University of Medical Sciences, Urmia, Iran. The authors are grateful to the Danesh Pey Hadi Company, a knowledge-based company of the Faculty of medicine, Urmia University of Medical Sciences for the support of the research.

All procedures and experiments were in accordance with the guidelines for the Care and Use of Experimental Animals outlined by the Laboratory Animal Center of the Urmia University of Medical Sciences and with the National Institutes of Health (NIH) Guide for Care and Use of Laboratory Animals. These procedures were approved by the Urmia Medical Science Research Ethics Committee (UMSREC) for biomedical researches.

The authors of this paper, F. G. Pakdel, S. Amirabadi, S. Naderi, M. A. Osalou, U. Cankurt, M. Jahanbani, and P. Shahabi, confirm that they have no conflict of interest.

Ф. Г. Пакдел,, , С. Амірабаді ${ }^{2}$, С. Надері ${ }^{3}$, М. А. Осалоу ${ }^{3}$, У. Канкурт ${ }^{4}$, М. Джаханбані, П. Шахабі,

ВПЛИВИ ГОСТРИХ ІНТРАЦЕРЕБРОВЕНТРИКУЛЯРНИХ МІКРОІНФУЗІЙ БУПРОПІОНУ НА ФОНОВУ ІМПУЛЬСНУ АКТИВНІСТЬ НЕЙРОНІВ БЛАКИТНОЇ ПЛЯМИ У ЩУРІВ

\footnotetext{
${ }^{1}$ Нейрофізіологічний дослідницький центр Урмійського університету медичних наук (Іран).

${ }^{2}$ Медичний факультет Урмійського університету медичних наук (Іран).
}

${ }^{3}$ Компанія Данеш Пей Хаді, Медичний факультет Урмійського університету медичних наук (Іран).

\section{${ }^{4}$ Медичний факультет Університету Докуз Сйлул, Ізмір} (Туреччина).

${ }^{5}$ Біологічний факультет Університету Пайаме Нуур, Тегеран (Іран).

${ }^{6}$ Дослідницький центр нейронаук Табризького університету медичних наук (Іран).

Резюме

Враховуючи, що норадренергічні (НАЕ) нейрони блакитної плями (locus coeruleus - LC) відіграють істотну роль у формуванні біологічних ритмів, болю, фармакологічних залежностей та розладів настрою, ми тестували впливи гострих інтрацеребровентрикулярних мікроінфузій антидепресанта бупропіону на фонову активність нейронів $L C$ у щурів. Уводили 10 мкл (тривалість інфузій 3 хв) розчинів, що вміщували різні дози $(0.001,0.01,0.1$, 1.0 або 10.0 мкмоль) бупропіону - інгібітора зворотного захоплення норадреналіну, що використовується в клініці як антидепресант. Імпульсну активність поодиноких нейронів $L C$ відводили позаклітинно скляними мікроелектродами. Мікроінфузії 0.01-10.0 мкмоль бупропіону дозозалежно пригнічували фонову імпульсацію цих нейронів. Середня нормована інтенсивність та тривалість гальмування складали в даних випадках 17.3, 19.4, 26.3 і 41.1 \% та 1.4, 7.1, 12.4 і 18.3 хв відповідно. Найменша доза бупропіону (0.001 мкмоль) була неефективною. Вважається, що бупропіон зумовлює підвищення рівнів цього катехоламіну в зоні розташування НАЕ-нейронів $L C$. Взаємодія бупропіону 3 іншими центральними нейромодуляторними системами потребує подальшого вивчення. Факт гальмування нейронної імпульсної активності в $L C$ під впливом бупропіону може сприяти інтерпретації особливостей гострих та хронічних впливів цього агента та його побічних ефектів при застосуванні в клініці для корекції розладів настрою.

\section{REFERENCES}

1. E. Szabadi, "Functional neuroanatomy of the central noradrenergic system," Psychopharmacology, 27, 659-693 (2013).

2. J. J. Schildkraut, "The catecholamine hypothesis of affective disorders. A review of supporting evidence," Int. J. Psychiat., 4, 203-217 (1967).

3. W. Potter, G. Grossman, and M. Rudorfer, "Noradrenergic function in depressive disorders," in: Biology of Depressive Disorders, J. Mann and D. Jupter (eds.), Plenum Press, New York (1993), pp. 1-27.

4. W. Kostowski, "Possible relationship of the locus coeruleushippocampal noradrenergic neurons to depression and mode of action of antidepressant drugs," Pol. J. Pharmacol. Pharm., 37, 727-743 (1985).

5. P. L. Delgado, "Depression: the case for a monoamine 
deficiency," J. Clin. Psychiat., 61, Suppl. 6, 7-11 (2000).

6. W. E. Bunney Jr. and J. M. Davis, "Norepinephrine in depressive reactions. A review," Arch. Gen. Psychiat., 13, 483494 (1965).

7. R. M. Hirschfeld, "History and evolution of the monoamine hypothesis of depression," J. Clin. Psychiat., 61, Suppl. 6, 4-6 (2000)

8. G. A. Ordway, K. S. Smith, and J. W. Haycock, "Elevated tyrosine hydroxylase in the locus coeruleus of suicide victims," J. Neurochem., 62, 680-685 (1994).

9. V. Chan-Palay and E. Asan, "Quantitation of catecholamine neurons in the locus coeruleus in human brains of normal young and older adults and in depression," J. Comp. Neurol., 287, 357-372 (1989).

10. M. M. Grant and J. M. Weiss, "Effects of chronic antidepressant drug administration and electroconvulsive shock on locus coeruleus electrophysiologic activity," Biol. Psychiat., 49, 117-129 (2001).

11. C. H. West, J. C. Ritchie, K. A. Boss-Williams, and J. M. Weiss, "Antidepressant drugs with differing pharmacological actions decrease activity of locus coeruleus neurons," Int. J. Neuropsychopharmacol., 12, 627-641 (2009).

12. C. H. West, J. C. Ritchie, and J. M. Weiss, "Addendum: Paroxetine-induced increase in activity of locus coeruleus neurons in adolescent rats: implication of a countertherapeutic effect of an antidepressant," Neuropsychopharmacology, 35, 1836-1837 (2010).

13. B. R. Cooper, C. M. Wang, R. F. Cox, et al., "Evidence that the acute behavioral and electrophysiological effects of bupropion (Wellbutrin) are mediated by a noradrenergic mechanism," Neuropsychopharmacology, 11, 133-141 (1994).

14. Y. Mateo, J. Pineda, and J. J. Meana, "Somatodendritic alpha2-adrenoceptors in the locus coeruleus are involved in the in vivo modulation of cortical noradrenaline release by the antidepressant desipramine," J. Neurochem., 71, 790-798 (1998).

15. S. Amirabadi, F. Ghaderi Pakdel, P. Shahabi, et al., "Microinfusion of bupropion inhibits putative GABAergic neuronal activity of the ventral tegmental area", Basic Clin. Neurosci., 5, 182-190 (2014).

15. G. Paxinos, and C. Watson, The Rat Brain in Stereotaxic Coordinates, Acad. Press Inc., San Diego (2007).

16. J. Pineda, L. Ugedo, and J. A. Garcia-Sevilla, "Stimulatory effects of clonidine, cirazoline and rilmenidine on locus coeruleus noradrenergic neurones: possible involvement of imidazoline-preferring receptors," Naunyn Schmiedebergs Arch. Pharmacol., 348, 134-140 (1993).

17. G. Aston-Jones and F. E. Bloom, "Norepinephrine-containing locus coeruleus neurons in behaving rats exhibit pronounced responses to non-noxious environmental stimuli," J. Neurosci., 1, No. 8, 887-900 (1981)

18. M. K. Borsody and J. M. Weiss, "Influence of corticotropinreleasing hormone on electrophysiological activity of locus coeruleus neurons," Brain Res., 724, 49-68 (1996).

19. S. L. Foote, G. Aston-Jones, and F. E. Bloom, "Impulse activity of locus coeruleus neurons in awake rats and monkeys is a function of sensory stimulation and arousal," Proc. Natl. Acad. Sci. USA, 77, 3033-3037 (1980).

20. J. Korf, B. S. Bunney, and G. K. Aghajanian, "Noradrenergic neurons: morphine inhibition of spontaneous activity," Eur. $J$. Pharmacol., 25, 165-169 (1974).

21. G. K. Aghajanian and C. P. VanderMaelen, "Alpha 2-adrenoceptor-mediated hyperpolarization of locus coeruleus neurons: intracellular studies in vivo," Science, 215, 1394$1396(1982)$.

22. J. M. Cedarbaum and G. K. Aghajanian, "Noradrenergic neurons of the locus coeruleus: inhibition by epinephrine and activation by the alpha-antagonist piperoxane," Brain Res., 112, 413-419 (1976).

23. P. E. Simson and J. M. Weiss, "Alpha-2 receptor blockade increases responsiveness of locus coeruleus neurons to excitatory stimulation," J. Neurosci., 7, 1732-1740 (1987).

24. V. M. Pickel, T. H. Joh, and D. J. Reis, "A serotonergic innervation of noradrenergic neurons in nucleus locus coeruleus: demonstration by immunocytochemical localization of the transmitter specific enzymes tyrosine and tryptophan hydroxylase," Brain Res., 131, 197-214 (1977).

25. L. Oreland and G. Engberg, "Relation between brain monoamine oxidase (MAO) activity and the firing rate of locus coeruleus neurons," Naunyn Schmiedebergs Arch. Pharmacol., 333, 235-239 (1986).

26. P. Blier and C. de Montigny, "Serotonergic but not noradrenergic neurons in rat central nervous system adapt to long-term treatment with monoamine oxidase inhibitors," Neuroscience, 14, 949-955 (1985).

27. R. J. Valentino, A. L. Curtis, D. G. Parris, and R. G. Wehby, "Antidepressant actions on brain noradrenergic neurons," $J$. Pharmacol. Exp. Ther, 253, 833-840 (1990).

28. J. J. Scuvee-Moreau and A. E. Dresse, "Effect of various antidepressant drugs on the spontaneous firing rate of locus coeruleus and dorsal raphe neurons in the rat," Eur. J. Pharmacol., 57, 219-225 (1979).

29. A. L. Curtis and R. J. Valentino, "Acute and chronic effects of the atypical antidepressant, mianserin, on brain noradrenergic neurons," Psychopharmacology (Berl), 103, 330-338 (1991).

30. R. Mongeau, M. Weiss, C. de Montigny, and P. Blier, "Effect of acute, short- and long-term milnacipran administration on rat locus coeruleus noradrenergic and dorsal raphe serotonergic neurons,". Neuropharmacology, 37, 905-918 (1998).

31. G. A. Ordway, J. Schenk, C. A. Stockmeier, et al., "Elevated agonist binding to alpha2-adrenoceptors in the locus coeruleus in major depression," Biol. Psychiat., 53, 315-323 (2003).

32. V. Klimek, C. Stockmeier, J. Overholser, et al., "Reduced levels of norepinephrine transporters in the locus coeruleus in major depression," J. Neurosci., 17, 8451-8458 (1997).

33. R. M. Ferris and B. R. Cooper, "Mechanism of antidepressant activity of bupropion," J. Clin. Psychiat., 11, 2-14 (1993).

34. B. R. Cooper, T. J. Hester, and R. A. Maxwell, "Behavioral and biochemical effects of the antidepressant bupropion (Wellbutrin): evidence for selective blockade of dopamine uptake in vivo," J. Pharmacol. Exp. Ther., 215, 127-134 (1980).

35. H. V. Nyback, J. R. Walters, G. K. Aghajanian, and R. H. Roth, "Tricyclic antidepressants: Effects on the firing rate of brain noradrenergic neurons," Eur. J. Pharmacol., 32, 302-312 (1975).

36. B. A. McMillen, W. Warnack, D. C. German, and P. A. Shore, "Effects of chronic desipramine treatment on rat brain noradrenergic responses to б-adrenergic drugs," Eur. J. Pharmacol., 61, 239-246 (1980).

37. C. Miguelez, L. Grandoso, and L. Ugedo, "Locus coeruleus and dorsal raphe neuron activity and response to acute antidepressant administration in a rat model of Parkinson's disease," Int. J. Neuropsychopharmacol., 14, 187-200 (2011). 